\title{
Unusually large peripheral giant cell granuloma- a case report
}

\author{
Dr. Munaza Shafi ${ }^{1}$, Dr. Reyaz Ahmed $\mathrm{Mir}^{2}$, Dr. Nawal Khan ${ }^{3}$, \\ Dr. Mir Yasser Abdullah ${ }^{4}$, Dr. Humaira Nazir ${ }^{5}$ \\ 1,2, (P.G.Student, Deptt.of Periodontics, Govt.Dental College, Srinagar) \\ 3,4, (Junior Resident, Govt.Dental College, Srinagar) \\ 5 (P.G.Student Oral And Maxillofacial Pathology,Sree Sidhartha dental College,tumkar)
}

\begin{abstract}
Peripheral giant cell granuloma (PGCG) is an infrequent exophytic lesion of the oral cavity, also known as giant cell epulis, osteoclastoma, giant cell reparative granuloma, or giant-cell hyperplasia. Lesions vary in appearance from smooth, regularly outlined masses to irregularly shaped, multilobulated protuberances with surface indentations. Ulcerations of the margin is occasionally seen. The lesions are painless, vary in size, and may cover several teeth. It normally presents as a soft tissue purplish-red nodule consisting of multinucleated giant cells in the background of mononuclear stromal cells and extravasated red blood cells. This article reports a peripheral giant cell granuloma arising at maxillary anterior region in 56 years old patient.
\end{abstract}

Keywords: Giant Cell, Granuloma, monocytes

\section{Introduction}

Peripheral giant cell granuloma (PGCG) is an infrequent exophytic lesion of the oral cavity, also known as giant cell epulis, osteoclastoma, giant cell reparative granuloma, or giant cell hyperplasia. ${ }^{1,2,3}$ PGCG is reactive lesion occurring on the gingiva and alveolar ridge usually as a result of local irritating factors such as tooth extraction, poor dental restorations, food impaction, ill fitting dentures, plaque, and calculus ${ }^{4}$. Lesions can be seen in young individuals but occurs in all age groups, it's more frequent in women than in men. ${ }^{5}$ Lesion can arise on facial and lingual gingival mucosa. PGCGs tend to be asymptomatic; however, while pain is uncommon, the lesion may become ulcerated as a result of repeated trauma ${ }^{6} \cdot$ Histologically, PGCG is described as a non-encapsulated mass of tissue, containing numerous multinucleate osteoclast-like giant cells lying in a very cellular and vascular stroma. The treatment is usually local surgical excision down to underlying bone along with scaling of adjacent teeth to remove any source of irritation and to minimize risk of recurrence. This paper describes the successful treatment of huge PGCGs in 56 years old patient.

\section{Case Presentation}

A 56 year old male patient reported to Department of Periodontics with a chief complaint of painless swelling in the upper front region of the mouth for the past 8 months and had grown progressively. His intraoral examination revealed a raised, round, sessile, smooth-edged mass $2 \mathrm{~cm}$ in diameter located on the maxillary anterior gingiva. The patient's general hygiene was not too good. There was accumulation of plaque and calculus. He was systemically healthy and was not taking any medication. Radiological examination revealed no evidence of bony involvement.

Extraoral examination revealed no any pathological findings, no facial asymmetry, no lymphadenopathy Anamnesis of the patient revealed no systemic diseases, examination of lymphnodes in the head and neck region revealed no lymphadenopathy. His blood tests included complete blood count, thyroid function test, liver function tests, and serum calcium, phosphorus, ionozed calcium and parathormone levels revealed normal results. The patient was informed regarding the diagnosis and treatment plan. Oral prophylaxis was performed and chlorhexidine $(0.12 \%)$ was recommended. Patient reported to the department after 7 days for the surgical excision of the lesion. The lesion was completely removed with the aid of scalpel under local anesthesia and the excised lesion was sent for histopathological examination. Routine histological examination with hematoxylin and eosin stain were performed. The microscopic features of the lesion were consistent with PGCG. A large number of stromal fibroblastic cells and multinucleated giant cells were seen. Postoperative healing was uneventful. Patient is still under follow up.

\section{Discussion}

PGCGs account for less than 10\% of all hyperplastic gingival lesions. These lesions have a reported average diameter of less than $20 \mathrm{~mm},{ }^{7}$ but the extent of their growth capacity is not well known. ${ }^{8}$ It is seen in the young as well as in the elderly population with highest incidence in the 4th to 6th decades of life. The 
preferential location of the lesion according to Pindborg is premolar and molar zone, though Shafer and Giansanti suggest that it generally occurs in the incisor and canine region. ${ }^{9}$ As the term "Giant cell epulis" implies, it occurs on the gingival margins or edentulous alveolar ridge as a focal purplish nodule in either the anterior or posterior regions of the jaws. The lesion can be sessile or pedunculated, spreading through penetration of the periodontal membrane and may or may not be ulcerated. Whereas in our case it occurs in maxilla.

The etiology of this lesion is still not precisely defined, local irritating factors such as tooth expulsion, ill-fitting prosthesis, poor restorations,plaque, calculus, chronic infections or the effects of nutrients may play a vital role in the etiology. The consistency of lesions was dependent on the age of lesions because as time passes, maturation of lesions (increasing in collagen fibers) occurs and consistency shifts from soft to firm. There are no pathogomic clinical features whereby these lesions can be differentiated from other forms of gingival enlargement. Microscopic examination is required for definitive diagnosis. The PGCG has numerous foci of multinuclear giant cells and hemosiderine particles in a connective tissue stroma. Areas of choronic inflammation are scattered throughout the lesion, with acute involvement occurring at the surface. The overlying epithelium is usually hyperplastic, with ulceratin at the baseline. ${ }^{10}$ In this case, all of these features were present. The differential diagnosis of PGCG includes lesions with very similar clinical and histological characteristics, such as central giant cell granuloma, which are located within the jaw itself and exhibit a more aggressive behavior. ${ }^{11}$ Only radiological evaluation can establish a distinction.

Traditional treatment consists of surgical resection of the lesion and elimination of the etiological factors. ${ }^{6,7}$ When the periodontal membrane is affected, full resection may require extraction of adjacent teeth ${ }^{7}$. As an alternative to surgery, carbon-dioxide laser resection involves less intra-operative bleeding, provides wound sterilization and requires no sutures. However, laser treatment is contraindicated in cases where the lesion is oriented close to the bone and where careful curettage is required. ${ }^{12}$ No malignant variations have been reported, and recurrence rates have been reported to range from $4.41 \%-50 \%$. ${ }^{6,12}$

\section{Conclusion}

Although the etiology was not exactly determined, low socioeconomic status of the patients and unfavorable oral hygiene seemed to be predisposing factors. Clinically it is difficult to diagnose the lesion differentially with other closely resembling lesions like pyogenic granuloma, peripheral ossifying fibroma and fibroma. Hence a histopathological examination of the tissue specimen is mandatory for confirming the diagnosis. In conclusion, for treating Peripheral Giant Cell Granuloma, a complete surgical excision along with its base and elimination of irritating factors seems satisfactory to prevent further recurrence.

\section{References}

[1]. Erdur O Khyan FT, Toprak MS, Aktas O. Peripheral giant cell granuloma: a case report. Bakirkoy Tip dergisi 2008;4:122-25

[2]. Yalcin E, Ertas U, Altas S. Peripheral giant cell granuloma: a retrospective study. Ataturk Univ Dis Hek Fak Derg 2010; 20 (1) : 34-37

[3]. Develioglu AH, Bostanci V, Nalbantoglu AM. Evaluation of Peripheral giant cell granuloma: a case report. Cumhuriyet Univ Dis Hek Fak Derg 9:1,2006; 9:1

[4]. Aslan M, Kaya GS, Day E, Demirci E. A Peripheral giant cell granuloma in early age (case report). Ataturk Univ Dis Hek Fak Derg 2006; 16 (3): 61-64

[5]. Giansant i JS, Waldron CA. Peripheral giant cell granuloma: review of 720 cases. J Oral Surg.1969;27:787-91

[6]. Gandara-Rey JM, Pacheco Martins Carneiro JL, Gandara-Vila P, et al. Peripheral giant-cell granuloma.Review of 13 cases. Med Oral 2002;7:254-259.

[7]. Grand E, Burgener E, Samson J,Lombardi T. Post-traumatic development of a peripheral giant cell granuloma in a child. Dent Traumatol 2008;24:124-126.

[8]. Bodner L, Peist M, Gatot A, Fliss DM.Growth potential of peripheral giant cell granuloma. Oral Surg Oral Med Oral Pathol Oral Radiol Endod 1997;83:548-551

[9]. Adlakha VK, Chandna P, Rehani U, Rana V, Malik P. Peripheral giant cell granuloma. J Indian Soc Pedod Prev Dent 2010; 28:293-6.

[10]. Carranza FA, Newman MG, Takei HH. Clinical periodontology.Ninth Edition, Chapter 202; 18:291

[11]. Karl R, Ugur MB, Bahadir B, Gul A, Uzun L, Giant cell reparative granuloma a case report. KBB Forum 2009; 8 (2):39-43

[12]. Chaparro-Avendaño AV, Berini-Aytés L, Gay-Escoda C. Peripheral giant cell granuloma. A report of five cases and review of the literature. Med Oral Patol Oral Cir Bucal2005;10:48-57.224 


\section{FIGURES}

Pre-operative view

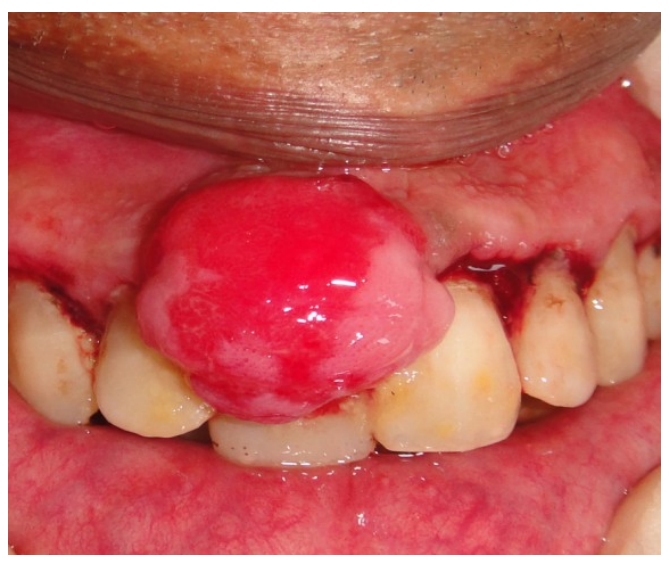

Surgical removal of the granuloma
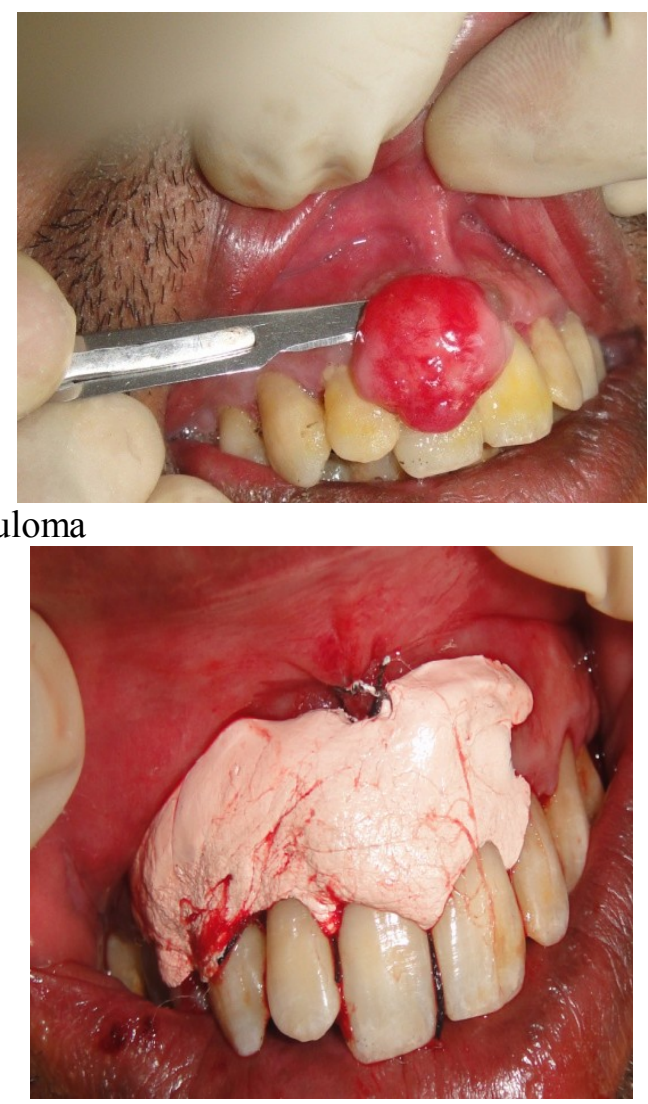

Sutures and periodontal pack placed

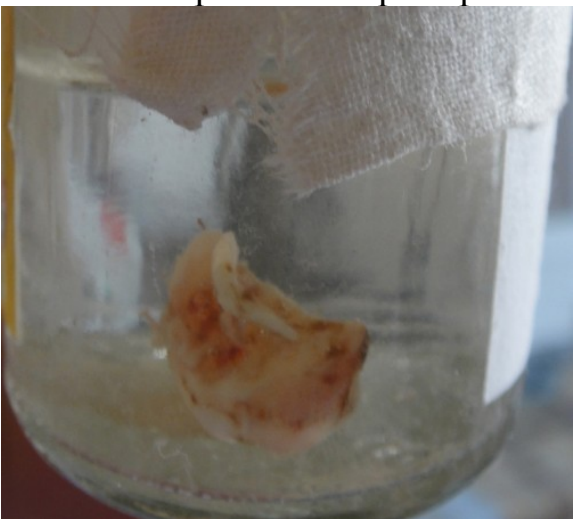

Sample sent for histopathological examination 


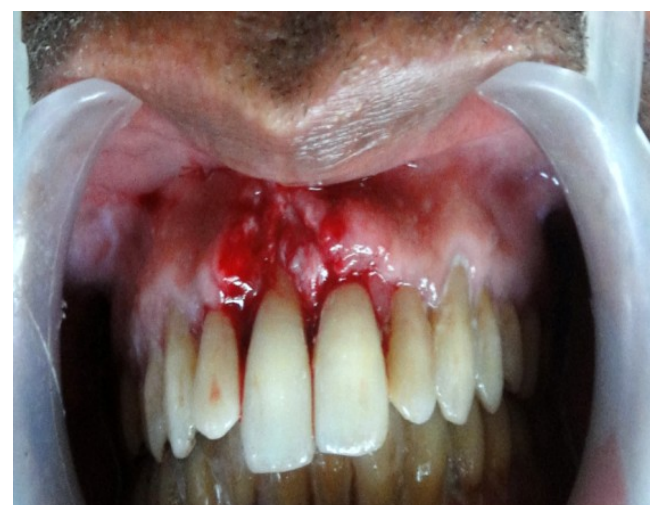

After sutures are removed

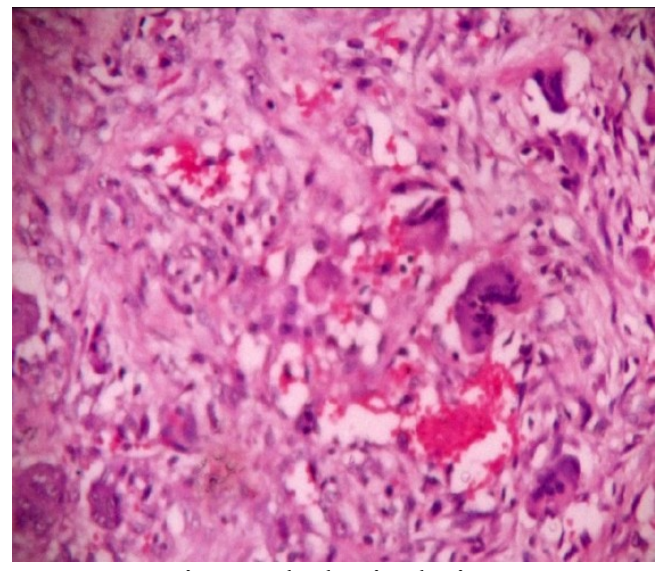

Histopathological view 